\title{
Weketrema gen. n., a new genus for Weketrema hawaiiense (Yamaguti, 1970) comb. n. (Digenea: Lecithasteridae) recently found in Australian marine fishes
}

\author{
Rodney A. Bray ${ }^{1}$ and Thomas H. Cribb ${ }^{2}$ \\ ${ }^{1}$ Department of Zoology, The Natural History Museum, Cromwell Road, London SW7 5BD, UK; \\ ${ }^{2}$ Department of Microbiology and Parasitology, The University of Queensland, Brisbane, Queensland 4072, Australia
}

Key words: Digenea, Lecithasteridae, Weketrema, Scolopsis, Plectorhinchus, Cheilodactylus, Latridopsis, Great Barrier Reef, Tasmania

\begin{abstract}
A new genus, Weketrema, is erected in the family Lecithasteridae for the species hitherto known as Lecithophyllum hawaiiense. Weketrema hawaiiense (Yamaguti, 1970) comb. n. is redescribed from Scolopsis bilineatus (Bloch) (Perciformes: Nemipteridae) from Lizard Island and Heron Island, Queensland, Plectorhinchus gibbosus (Lacepède) (Perciformes: Haemulidae) from Heron Island and Cheilodactylus nigripes Richardson (Perciformes: Cheilodactylidae) and Latridopsis forsteri (Castelnau) (Perciformes: Latridae) from Stanley, northern Tasmania. The new genus is distinguished from related members of the family Lecithasteridae by its complete lack of a sinus-sac. Although placed in the subfamily Lecithasterinae pro tem, its true subfamily position is not entirely clear. Comment is made on its unusual distribution, both in terms of zoogeography and hosts.
\end{abstract}

As more lecithasterid species are examined and emphasis is placed on the structure of the terminal genitalia, more unusual features are uncovered. This paper is a report of a known species, Lecithophyllum hawaiiense Yamaguti, 1970, re-examined using newly collected Australian material, Differential Interference Contrast (DIC) microscopy and serial sections. The structure of the terminal genitalia turns out to be different from that previously described in the group, such that it seems advisable that a new genus is erected.

\section{MATERIALS AND METHODS}

Digeneans collected from freshly killed fishes were fixed by being pipetted into nearly boiling saline and immediately preserved in $5 \%$ formalin or $70 \%$ ethanol. Wholemounts were stained with Mayer's haematoxylin, cleared in methyl salicylate and mounted in Canada balsam. Measurements were made through a drawing tube on an Olympus BH-2 microscope, using a Digicad Plus digitising tablet and Carl Zeiss KS100 software adapted by Imaging Associates, and are quoted in micrometres. The following abbreviations are used: $\mathrm{BMNH}$, the British Museum (Natural History) collection at The Natural History Museum, London, UK; QM, Queensland Museum collection, Brisbane, Australia; USNPC, United States National Parasite Collection; IP, collection at the Institute of Parasitology, ASCR, České Budějovice, Czech Republic. Fish synonymy is based on Froese and Pauly (2000).

\section{RESULTS}

Family L e c ith a s t e rid a e Odhner, 1905

Subfamily L e c i th a s t e r in a e Odhner, 1905

\section{Weketrema gen. n.}

Diagnosis. Lecithasteridae: Lecithasterinae. Body small, elongate oval. Tegument unarmed. Pre-oral lobe distinct. Oral sucker subglobular, subterminal. Ventral sucker oval, pre-equatorial. Prepharynx absent. Pharynx oval. Oesophagus short or apparently absent. Intestinal bifurcation in mid-forebody. Drüsenmagen present. Caeca reach close to posterior extremity, end blindly. Testes 2, oblique to symmetrical, in anterior hindbody. Seminal vesicle saccular, mainly in posterior forebody. Pars prostatica vesicular, oval; gland-cell sheath delimited by narrow membrane. Sinus-sac and sinus-organ absent. Hermaphroditic duct naked, globular or collapsed. Genital atrium deep. Genital pore median, in mid-forebody. Ovary oval, entire, post-testicular. Seminal receptacle blind. Laurer's canal absent. Uterus almost entirely in hindbody, may almost fill hindbody anterior to vitellarium, may extend slightly into postvitelline region. Eggs relatively large for hemiuroids, tanned, operculate. Metraterm distinct. Vitellarium consists of seven oval lobes, closely posterior to ovary. Excretory pore more or less terminal. Excretory vesicle divides in anterior hindbody; arms unite dorsally to pharynx.

T y p e-s p e c i e s : Weketrema hawaiiense (Yamaguti, 1970) comb. $n$.

E t y m o log y : Weke: Hawaiian common name of some of the mullid hosts of this species (Froese and Pauly 2000).

Address for correspondence: R.A. Bray, Department of Zoology, The Natural History Museum, Cromwell Road, London SW7 5BD, UK. Phone: ++44 207942 5752; Fax: ++ 44207942 5151; E-mail: r.bray@nhm.ac.uk 
Weketrema hawaiiense (Yamaguti, 1970) gen. n., comb. $\mathrm{n}$. Figs. 1-3

Syn. Lecithophyllum hawaiiense Yamaguti, 1970

Description. Based on 22 wholemount specimens and one set of serial sections. Measurements in Table 1. Body small, elongate oval (Fig. 1). Tegument unarmed. Pre-oral lobe distinct. Oral sucker subglobular, subterminal. Ventral sucker oval, larger than oral sucker, just pre-equatorial. Pharynx oval. Oesophagus short or apparently absent. Intestinal bifurcation in mid-forebody. Drüsenmagen present. Caeca reach close to posterior extremity, end blindly.

Testes 2, subglobular to oval, entire, oblique to symmetrical, contiguous or close, in anterior hindbody. Seminal vesicle saccular, oval to subglobular, in posterior forebody, may overlap ventral sucker slightly, connected to pars prostatica by narrow, relatively thickwalled duct. Pars prostatica vesicular, oval, but narrowing proximally, with wide lumen, lined with anuclear cell-like bodies, surrounded by distinct sheath of large gland-cells, delimited by narrow-membrane. Sinus-sac and sinus-organ absent. Hermaphroditic duct naked, globular or collapsed, with distinct, single-layered wall, delimited from genital atrium by distinct distal narrowing (Figs. 2, 3). Genital atrium deep, more a deep relatively wide invagination of surface than a narrow tubular duct, with complex folded muscular walls, often with overhanging antero-lateral muscular lips and single posterior muscular lip, giving inverted T-shaped lumen in ventral view. Hermaphroditic duct and genital atrium surrounded by gland-cells. Genital pore median, in midforebody; aperture may be inverted T-shaped (reflecting shape of genital atrium), slit-like or gaping.

Ovary oval, entire, post-testicular, usually distinctly separated from posterior testis. Mehlis' gland posterodorsal to ovary. Seminal receptacle globular, blind, dorsal to ovary. Laurer's canal absent. Uterus almost entirely in hindbody, may develop to almost fill most of hindbody anterior to vitellarium, does not extend more than slightly into post-vitelline region. Eggs relatively large for hemiuroids, tanned, operculate. Metraterm distinct, rectilinear, in posterior forebody, joins hermaphroditic duct laterally, through sphincter. Vitellarium consists of seven oval lobes, postero-ventral or ventrolateral to ovary.

Excretory pore more or less terminal. Excretory vesicle divides in anterior hindbody; arms unite dorsally to pharynx.

T y p e-h o s t a n d 1 o c a 1 i t y : Parupeneus porphyreus (Jenkins) (Perciformes, Mullidae), Hawaii (Yamaguti, 1970).

$\mathrm{New}$ records:

ex Scolopsis bilineatus (Bloch) (Perciformes: Nemipteridae). Stomach. Lizard Island, Queensland (14\%40'S, 154²8'E; April 1997). Prevalence: $10 \%$ (4/39). QM G217746-8, BMNH 2000.11.3.1-2, IP D-451. ex Scolopsis bilineatus (Bloch) (Perciformes: Nemipteridae). Stomach. Heron Island, Queensland (23⒉ $27^{\prime}$ S, 151 ${ }^{\circ} 55^{\prime} \mathrm{E}$; Jan. 1996). Prevalence: 2\% (1/51). QM G217749.

ex Plectorhinchus gibbosus (Lacepède) (Perciformes: Haemulidae). Stomach. Heron Island, Queensland (23⒉' S, $151^{\circ} 55^{\prime} \mathrm{E}$; July 1997). Prevalence: $100 \%$ (1/1). QM G2177502, BMNH 2000.11.3.3-4.

ex Cheilodactylus nigripes Richardson (Perciformes: Cheilodactylidae). Stomach. Stanley, northern Tasmania (4046'S, $145^{\circ} 20$ 'E; Dec. 1999). Prevalence: $100 \%$ (2/2). QM G217753-7, BMNH 2000.11.3.5-6.

ex Latridopsis forsteri (Castelnau) (Perciformes: Latridae). Stomach. Stanley, northern Tasmania $\left(40^{\circ} 46^{\prime} S, 145^{\circ} 20^{\prime} \mathrm{E}\right.$; Dec. 1999). Prevalence: $25 \%$ (2/8). QM G217758-60, BMNH 2000.11.3.7.

Previous records:

1. Yamaguti (1970); 2. Dyer et al. (1988).

Description: 1 .

D e f i n i t i v e hos t s : Mullidae: Mulloidichthys flavolineatus [as M. samoensis] (1), M. pfluegeri (1), Parupeneus bifasciatus (1), P. porphyreus (1), P. spilurus (2).

D i s tr i b u t i o n : Hawaii (1), Okinawa (2).

\section{DISCUSSION}

The terminal genitalia of this form are distinct from that described in any other lecithasterid. The proximal part of the hermaphroditic region of the terminal genitalia is in fact very different from a conventional sinus-sac. Usually the hermaphroditic duct is relatively tubular, with a distinct gap, usually filled with fibrous connective tissue and a few gland-cells, between the wall of the hermaphroditic duct and the wall of the sinus-sac. In this case the sinus-sac is, apparently, absent and what remains can be described as a globular or collapsed, naked hermaphroditic duct. This new genus is not readily accommodated in any of the lecithasterid subfamilies as recognised by Gibson and Bray (1979). In general morphology it resembles lecithasterine genera such as Lecithophyllum Odhner, 1905, in which it was originally placed, and Aponurus Looss, 1907, but all lecithasterine genera have a distinct, well-developed sinus-sac. The Prolecithinae Yamaguti, 1971, represented by the single genus Prolecitha Manter, 1961, which lacks a sinus-sac and has a rather complex arrangement of the genital atrium (Abdul-Salam and Khalil 1987), but details of the terminal genitalia do not resemble those of Weketrema. Other features, such as the cyclocoel and multilobate ovary, indicate that the relationship is not close. The mainly pre-ovarian uterus might be considered to indicate an affinity with members of the Trifoliovariinae Yamaguti, 1958, and some species of this latter subfamily have weakly developed sinus-sacs (Bray and Cribb 2000a). Again, details of the terminal genitalia do not indicate a close relationship, nor does the structure of the vitellarium, which consists of seven or eight 


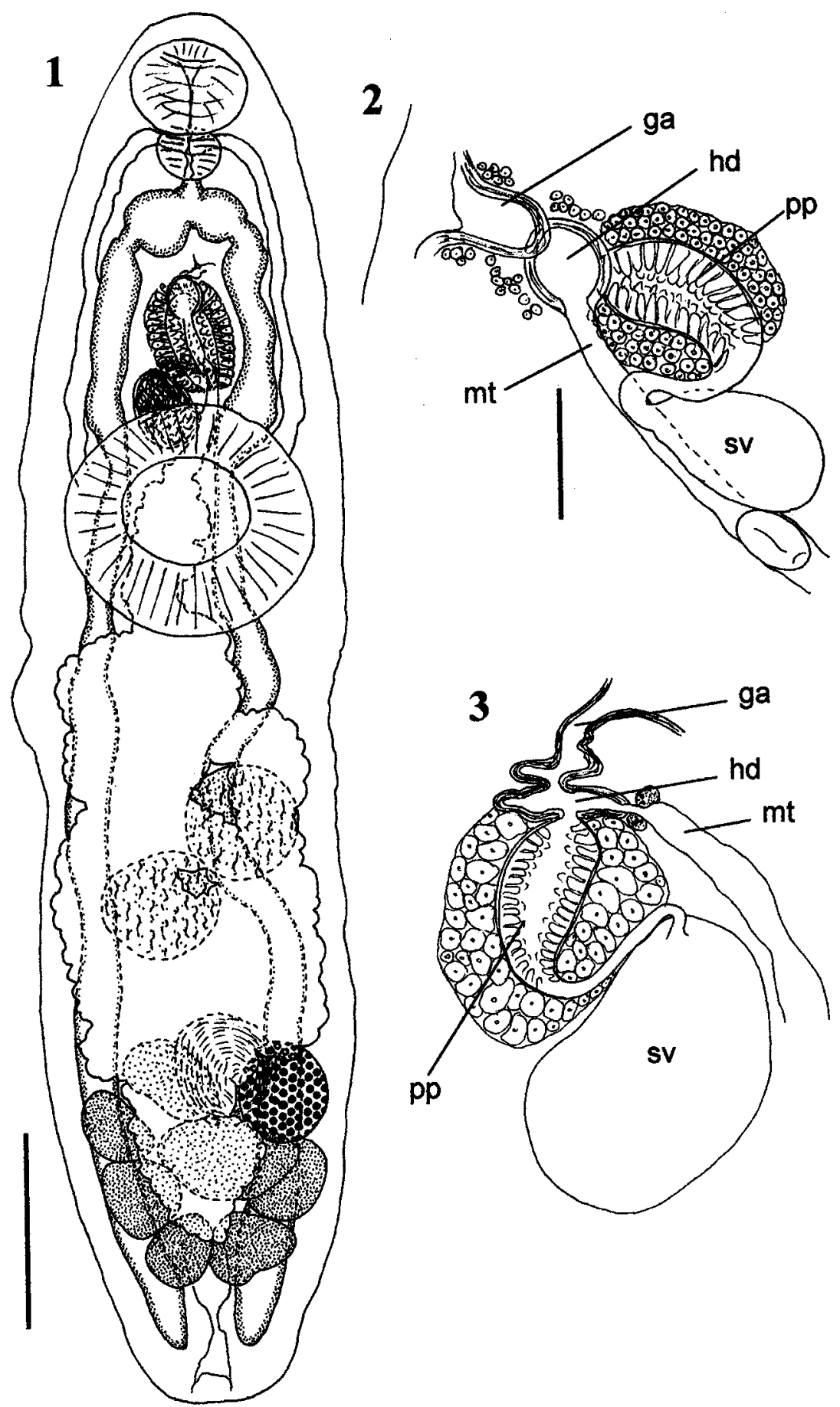

Figs. 1-3. Weketrema hawaiiense (Yamaguti, 1970). Fig. 1. Ventral view, specimen from Scolopsis bilineatus, uterus in outline. Fig. 2. Terminal genitalia in lateral view in wholemount, specimen from S. bilineatus. Fig. 3. Terminal genitalia, showing 'collapsed' hermaphroditic duct, reconstructed from serial sections, specimen from Cheilodactylus nigripes. ga - genital atrium; hd - hermaphroditic duct; $\mathrm{mt}$ - metraterm; $\mathrm{pp}$ - pars prostatica; sv - seminal vesicle. Scale bars $=200 \mu \mathrm{m}$. 
Table 1. Dimensions in $\mu \mathrm{m}$ of Weketrema hawaiiense (Yamaguti, 1970)

\begin{tabular}{|c|c|c|c|c|c|c|c|c|c|}
\hline \multirow[t]{2}{*}{$\begin{array}{l}\text { Host } \\
\text { Locality } \\
\mathrm{n}\end{array}$} & \multicolumn{3}{|c|}{$\begin{array}{c}\text { Scolopsis bilineatus } \\
\text { Great Barrier Reef } \\
6\end{array}$} & \multicolumn{3}{|c|}{$\begin{array}{c}\text { Plectorhinchus gibbosus } \\
\text { Great Barrier Reef } \\
5\end{array}$} & \multicolumn{3}{|c|}{$\begin{array}{c}\text { Latridopsis forsteri } \\
\text { Tasmania } \\
4\end{array}$} \\
\hline & $\min$ & $\max$ & mean & $\min$ & $\max$ & mean & $\min$ & $\max$ & mean \\
\hline Length & 859 & 1,298 & 1,145 & 1,710 & 2,040 & 1,852 & 1,281 & 1,628 & 1,480 \\
\hline Width & 245 & 310 & 287 & 325 & 380 & 346 & 295 & 392 & 360 \\
\hline Forebody & 324 & 434 & 373 & 484 & 525 & 502 & 416 & 529 & 458 \\
\hline Pre-oral lobe & 16 & 27 & 22 & 18 & 28 & 22 & 22 & 37 & 30 \\
\hline Oral sucker length & 68 & 100 & 89 & 115 & 129 & 120 & 104 & 124 & 113 \\
\hline Oral sucker width & 90 & 116 & 106 & 133 & 149 & 142 & 126 & 145 & 134 \\
\hline Pharynx length & 43 & 58 & 50 & 63 & 70 & 66 & 60 & 66 & 63 \\
\hline Pharynx width & 48 & 64 & 58 & 69 & 81 & 74 & 64 & 73 & 68 \\
\hline Oesophagus & 0 & 11 & 5 & 0 & 7 & 3 & 0 & 5 & 2 \\
\hline IB to VS & 169 & 275 & 213 & 289 & 323 & 306 & 227 & 344 & 282 \\
\hline Hermaphroditic duct length & 36 & 36 & 36 & 25 & 67 & 47 & 35 & 49 & 41 \\
\hline Hermaphroditic duct width & 32 & 32 & 32 & 25 & 51 & 40 & 15 & 51 & 38 \\
\hline GP to VS & 100 & 191 & 136 & 175 & 211 & 187 & 154 & 237 & 186 \\
\hline Ventral sucker length & 163 & 238 & 209 & 270 & 296 & 282 & 216 & 275 & 240 \\
\hline Ventral sucker width & 166 & 245 & 219 & 289 & 317 & 302 & 220 & 281 & 252 \\
\hline VS to AT & 10 & 120 & 61 & 148 & 313 & 199 & 20 & 138 & 106 \\
\hline Anterior testis length & 74 & 135 & 103 & 121 & 174 & 150 & 79 & 126 & 96 \\
\hline Anterior testis width & 67 & 122 & 95 & 121 & 191 & 158 & 76 & 121 & 98 \\
\hline AT to PT & 0 & 3 & 0 & 0 & 140 & 35 & 5 & 51 & 36 \\
\hline Posterior testis length & 65 & 116 & 99 & 111 & 145 & 135 & 84 & 131 & 100 \\
\hline Posterior testis width & 60 & 116 & 93 & 112 & 166 & 142 & 81 & 125 & 99 \\
\hline $\mathrm{PT}$ to $\mathrm{Ov}$ & 0 & 110 & 43 & 59 & 192 & 122 & 49 & 116 & 98 \\
\hline Ovary length & 53 & 148 & 105 & 132 & 187 & 154 & 105 & 122 & 116 \\
\hline Ovary width & 62 & 142 & 111 & 150 & 210 & 172 & 110 & 161 & 129 \\
\hline Vitelline field length & 114 & 239 & 210 & 273 & 331 & 299 & 201 & 312 & 232 \\
\hline Vitelline field width & 135 & 239 & 199 & 269 & 311 & 295 & 186 & 246 & 217 \\
\hline Post-vitelline region & 26 & 103 & 76 & 100 & 152 & 122 & 82 & 170 & 111 \\
\hline Post-uterine region & 60 & 158 & 110 & 99 & 173 & 130 & 91 & 136 & 118 \\
\hline Post-caecal region & 33 & 53 & 42 & 28 & 90 & 57 & 31 & 57 & 43 \\
\hline Egg length & 27 & 32 & 30 & 28 & 32 & 30 & 36 & 39 & 37 \\
\hline Egg width & 15 & 19 & 18 & 17 & 22 & 19 & 15 & 19 & 17 \\
\hline Width $\% *$ & 24 & 28 & 25 & 16 & 22 & 19 & 22 & 28 & 24 \\
\hline Forebody $\% *$ & 28 & 38 & 33 & 25 & 30 & 27 & 28 & 33 & 31 \\
\hline Sucker-ratio & 1.8 & 2.2 & 2.1 & 2.0 & 2.2 & 2.1 & 1.7 & 2.0 & 1.9 \\
\hline OS: Pharynx ratio & 1.7 & 1.9 & 1.8 & 1.8 & 2.1 & 1.9 & 1.9 & 2.1 & 2.0 \\
\hline PVR \% * & 2.2 & 8.5 & 6.7 & 5.6 & 8.6 & 6.6 & 5.0 & 10 & 7.5 \\
\hline PUR \%* & 5.4 & 12 & 10 & 4.9 & 9.8 & 6.6 & 6.6 & 10 & 8.0 \\
\hline PT-Ov \% * & 0.0 & 8.5 & 3.5 & 3.5 & 9.8 & 6.4 & 3.8 & 8.1 & 6.5 \\
\hline VS-AT * & 0.9 & 9.2 & 5.2 & 8.3 & 16 & 11 & 1.6 & 9.6 & 7.0 \\
\hline AT-PT * & 0.0 & 0.2 & 0.0 & 0.0 & 6.8 & 1.7 & 0.4 & 3.1 & 2.3 \\
\hline
\end{tabular}

* of body length, AT - anterior testis, GP - genital pore, IB - intestinal bifurcation, OS - oral sucker, Ov - ovary, PT - posterior testis, PUR - post-uterine region, PVR - post-vitelline region, VS - ventral sucker

elongate and, sometimes, branched lobes in trifoliovariines (Bray and Cribb 2000a). The 'fragility' of the present systematics of hemiuroid families and subfamilies is emphasised by recent molecular (Blair et al. 1998; Cribb et al. 2001) and morphological (Bray and Cribb 2000b) results, but the general morphological resemblance of Weketrema to lecithasterines has prompted us to place this new genus in that subfamily, awaiting further developments in hemiuroid systematics.

Despite discrepancies between our description and that of Yamaguti (1970), we consider that this form from four perciform host species at two sites on the Great Barrier Reef (GBR) and one from northern 
Table 1. Continued.

\begin{tabular}{|c|c|c|c|c|c|c|c|}
\hline \multirow[t]{2}{*}{$\begin{array}{l}\text { Host } \\
\text { Locality } \\
n\end{array}$} & \multicolumn{3}{|c|}{$\begin{array}{c}\text { Cheilodactylus nigripes } \\
\text { Tasmania } \\
6\end{array}$} & \multicolumn{3}{|c|}{$\begin{array}{c}\text { Parupeneus porphyreus } \\
\text { Hawaii } \\
5\end{array}$} & \multirow[t]{2}{*}{$\begin{array}{c}\text { Parupeneus spilurus } \\
\text { Okinawa } \\
1\end{array}$} \\
\hline & $\min$ & $\max$ & mean & $\min$ & $\max$ & mean & \\
\hline Length & 1,361 & 1,734 & 1,448 & 1,522 & 2,380 & 2,043 & 1,437 \\
\hline Width & 266 & 384 & 316 & 360 & 478 & 425 & 273 \\
\hline Forebody & 382 & 549 & 461 & 355 & 660 & 557 & 259 \\
\hline Pre-oral lobe & 12 & 31 & 22 & 12 & 37 & 24 & 14 \\
\hline Oral sucker length & 97 & 144 & 110 & 121 & 141 & 131 & 128 \\
\hline Oral sucker width & 121 & 165 & 135 & 142 & 175 & 161 & 136 \\
\hline Pharynx length & 47 & 72 & 57 & 59 & 74 & 66 & 64 \\
\hline Pharynx width & 61 & 83 & 69 & 59 & 75 & 70 & 56 \\
\hline Oesophagus & 0 & 8 & 5 & 0 & 28 & 16 & 5 \\
\hline IB to VS & 230 & 326 & 281 & 157 & 405 & 336 & 95 \\
\hline Hermaphroditic duct length & 23 & 56 & 41 & 33 & 37 & 35 & \\
\hline Hermaphroditic duct width & 39 & 51 & 46 & 34 & 39 & 36 & \\
\hline GP to VS & 168 & 236 & 188 & 115 & 270 & 219 & 80 \\
\hline Ventral sucker length & 212 & 310 & 246 & 294 & 381 & 341 & 263 \\
\hline Ventral sucker width & 219 & 337 & 257 & 281 & 368 & 328 & 271 \\
\hline VS to AT & 77 & 133 & 97 & 58 & 307 & 186 & 205 \\
\hline Anterior testis length & 108 & 129 & 120 & 111 & 140 & 127 & 99 \\
\hline Anterior testis width & 107 & 127 & 119 & 56 & 128 & 97 & 93 \\
\hline AT to PT & 0 & 51 & 14 & 8 & 56 & 36 & 17 \\
\hline Posterior testis length & 100 & 138 & 120 & 98 & 143 & 125 & 90 \\
\hline Posterior testis width & 100 & 136 & 117 & 75 & 126 & 103 & 93 \\
\hline $\mathrm{PT}$ to $\mathrm{Ov}$ & 0 & 133 & 81 & 133 & 443 & 237 & 148 \\
\hline Ovary length & 108 & 164 & 133 & 98 & 143 & 127 & 89 \\
\hline Ovary width & 130 & 163 & 142 & 109 & 157 & 141 & 107 \\
\hline Vitelline field length & 183 & 241 & 209 & 160 & 368 & 260 & 194 \\
\hline Vitelline field width & 202 & 253 & 226 & 182 & 307 & 238 & 151 \\
\hline Post-vitelline region & 90 & 111 & 97 & 157 & 257 & 194 & 129 \\
\hline Post-uterine region & 83 & 194 & 124 & 26 & 109 & 77 & 133 \\
\hline Post-caecal region & 37 & 66 & 50 & 7 & 75 & 38 & $22-25$ \\
\hline Egg length & 32 & 42 & 37 & 31 & 35 & 32 & 31 \\
\hline Egg width & 12 & 20 & 17 & 15 & 18 & 16 & 15 \\
\hline Width $\% *$ & 19 & 23 & 22 & 18 & 26 & 21 & 19 \\
\hline Forebody $\% *$ & 28 & 34 & 32 & 23 & 34 & 27 & 18 \\
\hline Sucker-ratio & 1.8 & 2.0 & 1.9 & 2.0 & 2.1 & 2.0 & 2.0 \\
\hline OS: Pharynx ratio & 1.8 & 2.1 & 2.0 & 2.1 & 2.4 & 2.3 & 2.4 \\
\hline PVR \%* & 5.4 & 8.0 & 6.8 & 8.0 & 11 & 10 & 9.0 \\
\hline PUR \% * & 6.1 & 11 & 8.5 & 1.5 & 4.6 & 3.7 & 9.2 \\
\hline PT-Ov \%* & 0.0 & 7.7 & 5.5 & 6.0 & 19 & 11 & 10 \\
\hline VS-AT * & 4.5 & 9.7 & 6.8 & 3.4 & 13 & 8.7 & 14 \\
\hline AT-PT * & 0.0 & 3.7 & 1.0 & 0.3 & 3.1 & 1.7 & 1.2 \\
\hline
\end{tabular}

Tasmania is conspecific with his Lecithophyllum hawaiiense. Using wholemounts and one set of serial sections, we interpret the terminal genitalia, which we feel are very distinctive for this form, rather differently from Yamaguti (1970). We have examined seven specimens from the type-host on the slide labelled USNPC 63795, including the specimen labelled 'type' and one specimen recovered by Dyer et al. (1988) (USNPC 79975) from Okinawa. The material is not particularly well fixed and much is considerably flattened, but, as far as we can tell using DIC microscopy, the terminal genitalia correspond to our interpretation of our material, rather than the arrangement illustrated by Yamaguti (1970). We have measured the dorso-ventrally mounted specimens in mullids from Hawaii and Okinawa and include these measurements in Table 1. These mullid specimens are, in general, larger than those from Australian waters and 
differ slightly in other ways from the quite variable Australian forms. Of the ratios given in Table 1, various features appear slightly distinct in the Australian specimens, including a longer forebody (overlapping), smaller ratio of pharynx width to oral sucker width (overlapping), shorter post-vitelline region (overlapping), longer post-uterine region, reflecting the fact that the uterus passes posteriorly to the vitellarium less frequently and to a lesser extent (overlap with Okinawa specimen - where the uterus does not extend posteriorly to the vitellarium), and shorter posterior testis to ovary length (overlapping). Whether these differences are of taxonomic significance is not readily decided. Some of the measurements may have been affected, possibly drastically, by flattening.

If it is accepted that Weketrema hawaiiense is, in fact, a widespread species then its host and geographical distribution is remarkable. Although reported from only five localities, these are so widely distributed that it seems certain that it must occur in many intermediate sites. A striking point is the fact that this species has been recovered from the cooler temperate waters of northern Tasmania in addition to the coral reefs of Hawaii, Okinawa and Queensland. Also extraordinary is the distribution in terms of hosts. All records are from perciforms. Early records were all from mullids, whereas we have found $W$. hawaiiense in a single species from each of the four families, Cheilodactylidae, Haemulidae, Latridae and Nemipteridae. Our examinations of mullids on the GBR are quite inadequate, however; only four specimens of two species, having been examined. From 119 specimens of 4 nemipterid species on the GBR, we have found this species at two localities in just one species. The range of families reported encompasses so much variation that it might be expected that many other perciform families would also be infected. The combination of the slight morphological distinctions between specimens from the various records in combination with the very unusual host and geographical distribution suggest that further study of this species is certainly warranted.

Acknowledgements. We are grateful to Rob Adlard, Clinton Chambers, Jess Morgan and Sylvie Pichelin for helping in the collection of this material and Trudy Wright for processing the material. The work was supported by the Australian Research Council, the Australian Biological Resources Study and the Heron Island Research Station. David Gibson kindly read the manuscript.

\section{REFERENCES}

ABDUL-SALAM J., KHALIL L.F. 1987: Two digeneans from the needlefish Ablennes hians in Kuwait and the description of a new genus and species, Neohaplosplanchnus ablennis (Haplosplanchnidae). Syst. Parasitol. 10: 149-158.

BLAIR D., BRAY R.A., BARKER S.C. 1998: Molecules and morphology in phylogenetic studies of the Hemiuroidea (Digenea: Trematoda: Platyhelminthes). Mol. Phyl. Evol. 9: $15-25$.

BRAY R.A., CRIBB T.H. 2000a: Species of Trifoliovarium Yamaguti, 1940 (Digenea: Lecithasteridae) from Australian waters, with a description of $T$. draconis $\mathrm{n}$. $\mathrm{sp}$. and a cladistic study of the subfamily Trifoliovariinae Yamaguti, 1958. Syst. Parasitol. 47: 183-192.

BRAY R.A., CRIBB T.H. 2000b: The status of the genera Hysterolecithoides Yamaguti, 1934, Neotheletrum Gibson \& Bray, 1979 and Machidatrema León-Règagnon, 1998 (Digenea: Hemiuroidea), including a description of $M$. leonae n. sp. from Australian waters. Syst. Parasitol. 46: 122.

CRIBB T.H., BRAY R.A., LITTLEWOOD D.T.J., PICHELIN S., HERNIOU E.A. 2001: The Digenea. In: D.T.J. Littlewood and R.A. Bray (Eds.), Interrelationships of the Platyhelminthes. Taylor \& Francis, London, pp. 168-185.

DYER W.G., WILLIAMS E.H., Jr., WILLIAMS L.B. 1988: Digenetic trematodes of marine fishes of Okinawa, Japan. J. Parasitol. 74: 638-645.

FROESE R., PAULY D. (Eds.) 2000: FishBase. World Wide Web electronic publication. http://www.fishbase.org.

GIBSON D.I., BRAY R.A. 1979: The Hemiuroidea: terminology, systematics and evolution. Bull. Br. Mus. Nat. Hist. Zool. 36: 35-146.

YAMAGUTI S. 1970: Digenetic Trematodes of Hawaiian Fishes. Keigaku Publishing, Tokyo, 436 pp. 